\title{
Best Ways to Develop Company Visits
}

\author{
Didier Roche \\ La Rochelle Business School, La Rochelle, France
}

\begin{abstract}
Nowadays, company visit seems to be a growing and changing market. Firms have switched from transactional marketing, the aim of which is to do business, to relationship marketing, which takes into consideration the customer as a real person. Firms now understand that in order to do business, customers must be well treated. Customer satisfaction is therefore very important, and that is the reason why managers are now opening their companies to customers. However, opening firms to the public cannot be improvised. This requires even now high technical tools. The purpose of this paper is to show how to implement successfully and effectively the company visit on a territory. In the first part, we define what company visit is. In the second part, we analyze the perspectives of six territorial advisers from several chambers of commerce (the body responsible for assisting companies in France). Thanks to their expertise, it is possible after analysing their discourse to propose methods to better develop company visits.
\end{abstract}

Keywords: industrial tourism, company visits, qualitative study

\section{Theoretical Setting of the Research}

Defining where this research lies theoretically comes back to clarifying what is meant by the concept of industrial tourism.

\section{Concept Definitions}

According to Preuilh (2006) and Gouault, Held, and Ficquelmont (1992), "Le tourisme de découverte économique" ("economic tourism" in English) is the most general and practical term used to refer to the different types of tourism to do with businesses and the economic world in general. However, it is possible for it to be considered as a generic term and so it is necessary to explain the different concepts that lie behind the term more clearly.

It is thus useful to distinguish among five (a non-exhaustive figure) kinds of business tourism.

Since the general term puts the emphasis on "economic" (Staunton, 2006), it is interesting to define what exactly is meant by the notion "economic tourism". It is a very broad term that can be understood to cover the group of activities that lead the public to visit a collection of places of interest in diverse sectors, be they primary, secondary, or tertiary.

Other designations that are used alongside the term but independently of it are scientific, technical, and industrial tourism. Included in these are company tours in all sectors but the agricultural sector (Bertrand, 2006a; 2006b).

The aim of technical tourism is the visiting of companies with an economic role and therefore excludes the visiting of museums (Acts of the 2nd European Congress of Industrial Tourism).

Didier Roche, associate professor, La Rochelle Business School. Email: roched@esc-larochelle.fr. 
Industrial tourism, the main term used to refer to the economic discovery of the French industrial heritage, seems too simplistic today as the industrial sector is the only sector included in the name.

Business tourism, despite the name, refers only to the different kinds of incentive trips offered to company personnel and can be accompanied by company tours.

Finally, the term company tour (Croix, 2006), at the same time both specific and more general in its field of application, can be understood as "any kind of physical opening to the public of a place of economic role in its working conditions or conditions that facilitate the imparting of know-how” (Gouault et al., 1992, p. 23). It is on the basis of this term, therefore, that our study will develop.

\section{Mobilised Concept Issues}

In France, companies wishing to open their doors to the public often have difficulty knowing what methodology to use to go at best. They therefore rely on the expertise of Chambers of Commerce and Industry to glean advice or to some polls (CSA Institute, 2008). These chambers have advisers who can help entrepreneurs. However, these advisors are not always trained to meet the demands of business and do not always have the desired information. In addition, there is no document in which the counselor Chambers of Commerce and Industry can refer.

\section{Methodology and Results of the Research}

\section{Presentation of the Methodology Used}

The goal is to identify existing best practices in order to compile a guide for entrepreneurs. For this purpose, emblematic counselors of Chambers of Commerce and Industry with experience of visiting company were interviewed to identify working methods that worked best. These interviews were conducted either by direct interviews and meetings with counselors or by a visit to the territory of work of counselors.

\section{Presentation of Results}

The results have allowed us to evidence several steps to follow before visiting a project business.

The first step is the first startup. Before entering into the operational phase, it is necessary to ask different questions: project definition: What are the objectives? What are the target audiences? What is the project (short or long-term)? What types of businesses will be visited? What are the partners involved? What are the available financial resources? And what is the "phasing” (the calendar)?

Then you have to identify what exists: You must identify the offer to visit the territory. There are actually many events in France, such as "Welcome to the Farm", "Craft Days", and "Vineyard and Discovery". In this way, companies can be visited. Finally, you should contact the companies and preferably the entrepreneur to be on site to verify the feasibility of the visit.

The second stage is marked by the councilors' project development. The first axis is to promote territorial marketing by enhancing local know-how by visiting: It will set up an annual calendar of occasional visits valuing expertise and dynamism of the territory while organizing the meeting with key economic players in the region. It will therefore primarily target the most innovative companies or the most representative of the territory. The target population will be local people who wish to discover businesses even if passing tourists themselves can also be affected. The public school students and business people (B to B) are also concerned. 
The generalist model can be "open days" type which is to open up the business to the public in a limited time (about a week). During those days, it is possible to choose a chain or a particular sector (e.g., eco-construction) or a theme (innovation) model. Special event that showcases a unique company can also be selected as an event in the context of a more global event (with open days for example) that can pool resources including communication and marketing. At least six months before it will find partners (technical or financial) and at least one month before, it will give the rules, for example, by reminding about the entrepreneur's safety, hospitality and guide visitors. During the event, it will be necessary to create mini-events (visit two or three companies for a day) and communicate with the press. After the event, it will be necessary to assess the action taken to make it evolve.

The second focus is to enhance the development of tourism in building a standing offer and qualified tour. This offer will target local visitors and tourists. The visit will become a strategic issue for companies or additional revenue. To do this, you must select the companies and help verify the feasibility of the project, helping to find financial support, to define schedules ideals of openness, regulatory compliance, and implementation site security. Similarly, it is possible to help the company create a website reservation to implement a circuit guide and adjust its trade policy for this job visit. Subsequently, the company may seek a label.

The third stage is marked by advisors' networking actors. To do some networking, all public companies have to create a territorial dynamics that facilitates adherence to corporate project. This also offers services-tailored training, exchange of experiences, sharing of resources (guide, bulk orders), communication (website presence in salons), and marketing (central reservation). Another way to structure the offer is through the creation of tour routes that can combine several kinds of offers: a thematic route, multi-product packages, tour packages, and catering or transportation of packages and tours (by bus).

\section{Conclusion}

The goals of this study were to clarify as much as possible the concept of the company tour in order to try to understand it better.

Tour operation business must be programmed for a limited period (three years). It must be regularly evaluated by the advisors of the Chamber of Commerce and Industry. This will assess the number of companies affected and labeled, the satisfaction of public business satisfaction, and the financial results of the operation. The counselor should always be looking for new businesses and create new synergies. It will also offer to change the visit by changing their offers to visit especially for new technologies (flash codes, videos) to make visits more fun and interactive. Simplifying and making visible the company visit is undoubtedly the future. Booking of development platforms is an example. It will also require the consultant to develop a business culture, exchanging visits with colleagues responsible for similar projects and learning other techniques at the national or international level.

\section{References}

Acts of the 2nd European Congress of Industrial Tourism, November 11-13, Toledo.

Bertrand, L. (2006a). Minister for tourism. Acts of the First European Symposium on the Company Tour, March 7-9, Angers.

Bertrand, L. (2006b). Symposium opening (p. 7). Acts of the First European Symposium on the Company Tour, March 7-9, Angers.

Croix, A. (2006). The company tour: Strategic communication tool (p. 18). Acts of the First European Symposium on the Company Tour, March 7-9, Angers. 
CSA Institute. (2008). The French, the Spanish, the image of companies and company open days. Survey by the CSA Institute No. 0801038B.

Gouault, P., Held, V., \& Ficquelmont, G. M. (1992). The visitor, company tour guide. Dunod.

Preuilh, P. (2006). The company tour in France (p. 9). Acts of the First European Symposium on the Company Tour, March 7-9, Angers.

Staunton, G. (2006). The company tour in Ireland (p. 21). Acts of the First European Symposium on the Company Tour, March 7-9, Angers. 